\title{
CREDIT FOR TIME SERVED BETWEEN ARREST AND SENTENCING
}

In $C o b b$ v. Bailey, ${ }^{1}$ the Fifth Circuit ruled that a state prisoner, indicted for a nonbailable offense and sentenced to the statutory maximum term, was not constitutionally entitled to receive credit for presentencing incarceration. Lillian Cobb was arrested and indicted for murder in the first degree, a nonbailable offense at that time under Alabama law. ${ }^{2}$ Six months later, she was convicted of second degree manslaughter, a misdemeanor, and sentenced to twelve months imprisonment in the county jail, the statutory maximum. ${ }^{3}$ She thus served eighteen months in jail, although she was convicted of an offense with a maximum sentence of twelve months.

The court, declining to overrule or distinguish its earlier decision in Gremillion v. Henderson, ${ }^{4}$ in which it had stated without qualification that "there is no federal constitutional right to credit for time served prior to sentence," rejected her contention that failure to give such credit violated her constitutional rights. Noting that Congress had passed legislation in 1966 requiring such credit to be given to federal prisoners, ${ }^{6}$ the court reasoned that, since such legislation had been deemed necessary, the right to such credit must not be constitutionally required. Rather, it concluded that the right to such credit is properly a creation of state statute or a matter within the discretion of the sentencing judge. ${ }^{7}$

The question whether credit for presentence confinement is constitutionally required has arisen infrequently for two reasons. Many courts have held that if the actual sentence plus presentence time does not exceed the statutory maximum sentence, there is a presumption that the sentencing judge gave credit for the presentence time. ${ }^{8}$ Thus,

1469 F.2d 1068 (5th Cir. 1972).

2 ALA. CODE tit. 15, \& 195 (1959).

3 ALA. CopE tit. 14, § 322 (1959).

4425 F.2d 1293 (5th Cir. 1970).

5 Id. at 1294.

${ }^{6} 18$ U.S.C. § $3568(1970)$. The purposes of the bill and the interpretation given it by the courts are discussed at notes 11-14 infra \& accompanying text.

7 Accord, e.g., Gremillion v. Henderson, 425 F.2d 1293 (5th Cir. 1970) ; Burns v. Crouse, 339 F.2d 883 (10th Cir. 1964); Jones v. Henry, 317 F. Supp. 1400 (E.D.N.C. 1970); Arsad v. Henry, 317 F. Supp. 162 (E.D.N.C. 1970); Gross v. Sarver, 307 F. Supp. 1105 (E.D. Ark. 1970); People v. Jones, 489 P.2d 596 (Colo. 1971); State v. Williams, 262 La. 769, 264 So.2d 638 (1972); Williams v. State, 2 Md. App. 170, 234 A.2d 260 (1967); State v. Crockrell, 470 S.W.2d 507 (Mo. 1971); Ibsen v. Warden, 86 Nev. 540, 471 P.2d 229 (1970); State v. Walker, 277 N.C. 403, 177 S.E.2d 868 (1970); State v. Virgil, 276 N.C. 217, 172 S.E.2d 28 (1970); Burns v. Page, 446 P.2d 622 (Okla. Crim. App. 1968); State v. Sanders, 251 S.C. 431,163 S.E.2d 220 (1968); Bennett v. State, 450 S.W.2d 652 (Tex. Crim. App. 1970).

8 See, e.g., Myers v. United States, 446 F.2d 232 (9th Cir. 1971); Holt v. United States, 422 F.2d 822 (7th Cir. 1970); Noorlander v. United States, 404 F.2d 603 (8th 
only prisoners like Lillian Cobb, whose combined time in prison exceeds the maximum sentence, have had standing to challenge the denial of such credit. And many legislatures have eliminated the problem by either requiring that credit be given for time spent in pretrial detention, or authorizing such credit at the discretion of the sentencing judge. ${ }^{9}$

This Comment deals only with the rights of an accused jailed for a nonbailable offense. ${ }^{10} \mathrm{It}$ is here contended that, when a prisoner is sentenced to a maximum term, a constitutional right to receive credit for presentence incarceration does exist.

The court's reasoning in $C o b b$ is not persuasive: it ignores the historical setting of the legislative process. The $1966 \mathrm{bill}^{11}$ clarified an earlier version ${ }^{12}$ by eliminating mention of a minimum mandatory sentence, which had been interpreted by some courts to be a requirement for the granting of credit for pretrial confinement. Ironically, before 1966 some judges had been denying credit in cases of offenses which had no minimum sentence. ${ }^{13}$ The passage of a statute which,

Cir. 1968); Huber v. United States, 390 F.2d 544 (5th Cir. 1968); Ashworth v. United States, 391 F.2d 245 (6th Cir. 1968); Stapf v. United States, 367 F.2d 326 (D.C. Cir. 1966). But see Pedgett v. United States, 387 F.2d 649 (4th Cir. 1967) (question of presentence credit is open for determination upon the particular facts of each case).

${ }^{9}$ See, e.g., 18 U.S.C. $\$ 3568$ (1970), discussed at notes 11-14 infra \& accompanying text; Itr. ANN. Stat. ch. 38, § 119-3 (Supp. 1972); Mass. GeN. Laws ch. 279, § 33A (1968); Pa. Stat. AnN. tit. 19, \& 894 (1964).

In the Fifth Circuit Georgia, GA. CODE ANN. \& 2530 (1972), Louisiana, LA. Code Crmo. Pro. art. 880 (Supp. 1972), and Mississippi, Miss. CODE Ann. \& 2540.5 (Supp. 1972), mandatorily award credit for pretrial incarceration. Florida, FLA. STAT. ANN. § 921.161 (1973), and Texas, Tex. COde Cror. Pro. ANn. art. 42.03 (Supp. 1972), grant the trial judge discretion whether to grant such credit. Alabama appears to have no law on the subject.

10 If the offense is bailable, and the accused remains in jail due solely to indigence, serious equal protection issues, beyond the scope of this Comment, arise. In 2 recent cases, Tate v. Short, 401 U.S. 395 (1971), and Williams v. Illinois, 399 U.S. 235 (1970), the Court ruled that it is unconstitutional for a state to force an indigent to work off a fine by incarceration. The court noted:

[O]nce the state has defined the outer limits of incarceration necessary to

satisfy its penological interests and policies, it may not then subject a certain class of convicted defendants to a period of imprisonment beyond the statutory maximum solely by reason of their indigency.

Id. at 241-42. Several courts have applied this rationale to the practice of denying credit for presentence incarceration in bailable cases. In such cases those who remain in jail prior to trial do so due solely to their indigence. This, these courts have held, is a violation of the equal protection clause. See, e.g., Hart v. Henderson, 449 F.2d 183 (5th Cir. 1971); United States v. Gaines, 449 F.2d 143 (2d Cir. 1971); White v. Gilligan, 351 F. Supp. 1012 (S.D. Ohio 1972); Workman v. Cardwell, 338 F. Supp. 893 (N.D. Ohio 1972); Parker v. Bounds, 329 F. Supp. 1400 (E.D.N.C. 1971); Culp v. Bounds, 325 F. Supp. 416 (W.D.N.C. 1971); cf. Williams v. Missouri Dep't of Corrections, 463 F.2d 993 (8th Cir. 1972). Importantly, it also should be noted that these cases implicitly reject the argument that there is sufficient difference between pre- and posttrial incarceration to warrant a constitutional distinction under the equal protection clause. See notes 25-30 infra \& accompanying text. Clearly those cases which reject the claim to credit, see note 7 supra, also implicitly reject the view that equal protection problems exist.

1118 U.S.C. $\$ 3568$ (1970) (first paragraph).

12 Act of Sept. 2, 1960, Pub. L. No. 86-691 \& 1(a), 74 Stat. 738, as amended 18 U.S.C. $\$ 3568(1970)$.

18 For an account of the legislative history of the 1966 enactment, see Stapf $v$. 
by clarifying an ambiguity in an earlier statute, guarantees a right to credit for pretrial incarceration, cannot realistically be said to negate the existence of a constitutional right to such credit. The existence of the statute may be a recognition or confirmation of the basic constitutional right; a conclusion that at least one court has reached. ${ }^{14}$ But even assuming, as the $C o b b$ court did, that the passage of the statute confirming the right strongly implies the absence of a constitutional basis for that right, relevant constitutional jurisprudence may have advanced since its passage. In fact, decisions such as North Carolina $v$. Pearce, ${ }^{15}$ Benton v. Maryland ${ }^{16}$ and United States $v$. Jackson ${ }^{17}$ have advanced relevant constitutional law far beyond its 1966 posture, eroding any support for the $C o b b$ holding furnished by the passage of the bill. Three constitutional bases emerge from which to derive a right to credit for presentencing incarceration: the double jeopardy clause, the unconstitutional conditions doctrine, and the cruel and unusual punishment clause.

\section{DOUBLE JEOPARDy}

There is a clear analogy between the present situation and that of successful appellants who seek credit for time served on their original conviction before retrial and resentencing. In North Carolina v. Pearce ${ }^{18}$ the Supreme Court held that failure to grant such credit would constitute double jeopardy in violation of the fourteenth amendment. ${ }^{19}$

United States, 367 F.2d 326 (D.C. Cir. 1966). The provision regarding a minimum mandatory sentence created a dilemma for some judges. Although it had been inserted to permit judges to give minimum sentences and to provide credit, see id. at 328; Short v. United States, 344 F.2d 550, 558 (1965); H.R. REP. No. 2058, 86th Cong., 2d Sess. (1960), some courts read the provision as granting credit only when a minimum mandatory sentence was provided. See, e.g., Sawyer v. United States, 376 F.2d 615 (8th Cir. 1967); Powers v. Taylor, 327 F.2d 498 (10th Cir. 1964); Scott v. United States, 326 F.2d 343 (8th Cir. 1964).

Stapf, which was followed by most circuits, held that the congressional intention in 1960 was to extend credit both to those sentences under statutes which had a minimum term, as well as to those which did not. Since no valid rationale justified distinguishing between the 2 types of offenses, the court reasoned that a contrary intention would violate either the due process or the equal protection clause. See, e.g., Myers v. United States, 446 F.2d 232 (9th Cir. 1971); Sobell v. United States, 407 F.2d 180 (2d Cir. 1969); Bryans v. Blackwell, 387 F.2d 764 (5th Cir. 1967); United States v. Smith, 379 F.2d 628 (7th Cir. 1967); Dunn v. United States, 376 F.2d 191 (4th Cir. 1967). But see Sawyer v. United States, 376 F.2d 615 (8th Cir. 1967); Allen v. United States, 264 F. Supp. 420 (M.D. Pa. 1966). Congress, recognizing the cogency of this argument, eliminated the wording in 1966. See S. REP. No. 750, 89th Cong., 1st Sess. 21 (1965).

14 See Mize v. United States, 323 F. Supp. 792 (N.D. Miss. 1971). Although this case is of little precedential value because of the controlling Fifth Circuit decisions in $C o b b$ and Gremillion, its reasoning is illuminating. The $C o b b$ court's argument that the passage of a statute implies the absence of a constitutionally-based right is untenable. Some statutes, see, e.g., 42 U.S.C. \& 1983 (1970), far from negating the existence of a constitutional right, are merely affirmative implementations of those rights.

15395 U.S. 711 (1969).

16395 U.S. 784 (1969).

17390 U.S. 570 (1968).

18395 U.S. 711 (1969).

10 See Benton v. Maryland, 395 U.S. 784 (1969). 
The double jeopardy clause prohibits multiple punishments as well as multiple conviction for the same offense. ${ }^{20}$ This guarantee is violated "when punishment already exacted for an offense is not fully 'credited' in imposing sentence upon a new conviction for the same offense."21 The Court in Pearce denoted the constitutional violation as "flagrantly apparent" and "dramatically evident" in cases involving the imposition of a maximum sentence upon reconviction, ${ }^{22}$ but was adamant that the principle involved was equally applicable to any punishment endured prior to reconviction.

The broad rationale of Pearce requires that full credit be given in the present situation. In both, the state has exacted punishment prior to conviction; in both, the prisoner will have served more time in prison than the statutory maximum. As one court, which found Pearce controlling, articulately noted:

Pre-trial detention is nothing less than punishment. An unconvicted accused who is not allowed ... bail is deprived of his liberty. His incarceration is indistinguishable in effect from that of one, such as Pearce, who is retried after obtaining post-conviction relief. In both instances, the power of the state has been utilized to punish the complainant. Fundamental notions of fair play as well as the double jeopardy clause require that [the defendant] receive credit for precommitment incarceration. ${ }^{23}$

Thus, a failure to grant full credit for presentence incarceration should be held to violate the double jeopardy clause. ${ }^{24}$ Unfortunately, many courts have not found this reasoning persuasive. Several rationales have been advanced for distinguishing Pearce.

Because under state law the sentence starts only after conviction, some courts hold that time spent in jail prior to conviction and sentencing is not punishment, but merely precautionary detention to assure the defendant's presence at trial. Because punishment is not involved, the double jeopardy clause is not operative. ${ }^{25}$ This apparently plausible argument cannot withstand a deeper examination. ${ }^{28}$

20 Ex parte Lange, 85 U.S. (18 Wall.) 163 (1873).

21395 U.S. at 718.

$22 I d$.

23 Culp v. Bounds, 325 F. Supp. 416, 419 (W.D.N.C. 1971).

24 See Parker v. Bounds, 329 F. Supp. 1400, 1401 (E.D.N.C. 1971) ; Culp v. Bounds, 325 F. Supp. 416, 419 (W.D.N.C. 1971). Cf. Wright v. Maryland Penitentiary, 429 F.2d 1101 (4th Cir. 1970).

25 See State v. Walker, 277 N.C. 403 , 177 S.E.2d 868 (1970); State v. Virgil, 276 N.C. 217,172 S.E.2d 28 (1970); State v. Sanders, 251 S.C. 431, 163 S.E.2d 220 (1968); Bennett v. State, 450 S.W.2d 652 (Tex. Crim. App. 1970).

26 This argument bears a striking resemblance to that advanced by some courts in denying credit for time served pursuant to a conviction later found void. These courts reasoned that since the original conviction was void, the time spent in prison was neither sentence nor punishment, but simply time spent in prison. See, e.g., Minto v. State, 9 Ala. App. 95, 64 So. 2d 369 (1913); Ex parte Wilkerson, 76 Okla. Crim. 204, 135 P.2d 
From the perspective of the prisoner this subtle distinction between pretrial preventive detention and postsentencing punishment is meaningless; in both he faces the same loss of freedom. As one court has noted:

Ohio contends that pretrial detention is not punishment because the defendant has not yet been convicted of a crime. Given the deplorable condition of most local jails, we find it difficult to characterize such confinement as anything but punishment. ${ }^{27}$

Regardless of the statutory purpose, the effect of any incarceration upon the person detained is punitive within the meaning of the double jeopardy clause. In an evaluation of constitutional rights, the effect of a practice upon the individual is determinative. ${ }^{28}$ Therefore, the pur-

507 (1943). Bult see King v. United States, 98 F.2d 291, 293-94 (D.C. Cir. 1938), recognizing the argument as a hollow legal fiction:

The Govermment's brief suggests in the vein of Mikado that because the

first sentence was void appellant 'has served no sentence but has merely spent time in the penitentiary ;' that since he should not have been imprisoned as he was, he was not imprisoned at all. ... As other corollaries it might be suggested that he is liable in quasi-contract for the value of his board and lodging, and criminally liable for obtaining them by false pretenses.

Id. See Whalen, Resentence Without Credit For Time Served; Unequal Protection of the Lawe, 35 MrNw. L. REv. 239, 240-43 (1951). Pearce implicitly rejects the argument as well. Of course, the mere resemblance of this argument for distinguishing Pearce to arguments rejected by Pearce does not destroy its validity. The slightest differences often become distinctions in constitutional law. Contrived legal fictions, however, should be frowned upon when vital civil liberties are involved.

27 White v. Gilligan, 351 F. Supp. 1012 (S.D. Ohio 1972); see Jones v. Whittenberg, 323 F. Supp. 93 (1971).

28 In re Gault, 387 U.S. 1 (1966). Gault rejected the contention that due process does not apply to juvenile criminal proceedings, because their purpose is to treat and rehabilitate, and the procedures used are "clinical" rather than punitive." Id. at 16. The Court noted that the practical effects of juvenile proceedings were the same as those of adult proceedings; therefore due process rights attached.

A boy is charged with misconduct. . . . It is of no constitutional consequence -and of limited practical meaning-that the institution to which he is committed is called an Industrial School. The fact of the matter is that, however euphemistic the title, ... the child is incarcerated for a greater or lesser time. ...

In view of this, it would be extraordinary if our Constitution did not require the procedure of regularity and the exercise of care implied in the phrase 'due process.'

Id. at 27-28. See Sawyer v. Clark, 386 F.2d 633 (D.C. Cir. 1967) (prisoner is entitled to credit for time spent in mental hospital for examination under 19 U.S.C. $\$ 3568$ ); United States ex rel. Pollock v. McGinness, 337 F. Supp. 1220 (S.D.N.Y. 1971) (state cannot distinguish between different forms of custody); State v. Lee, 60 N.J. 53, 286 A.2d 52 (1972) (prisoner entitled to credit for time spent in diagnostic center for observation after sex offense, under statute requiring credit for term of "custodial sentence" between arrest and imposition of sentence).

The statement in the text is intended to mean only that a practice unconstitutional in effect should not be saved by reference to statutory purpose. There are, of course, situations in which an improper motive on the part of the state or its agents will impart a constitutional taint to an otherwise allowable practice. See, e.g., Reitman v. Mulkey, 387 U.S. 369 (1967).

Constitutional safeguards like the due process and double jeopardy clauses are preeminently intended for the protection of individual rights, and limit state power only by necessary implication. One can only speculate on the extent to which contemporary focus on curbing police and prosecutorial abuse has led some courts to apply the vitiating factors of improper purpose and improper effect only conjunctively. 
pose of the detention should not alter the conclusion that Pearce controls.

It has been argued that Pearce is distinguishable from the pretrial confinement problem, because in Pearce punishment was inflicted after two trials, while only one is involved in the former situation. ${ }^{29}$ This argument, however, ignores the fact that Pearce applied double jeopardy because two penalties were meted out, not because two convictions were incurred. ${ }^{30}$ If the key to the problem is the punishment, and not the conviction, then the fact that in the present case the first punishment is imposed upon arrest rather than upon conviction is irrelevant.

Courts have also limited Pearce's application to prisoners whose noncredited time is spent in a penitentiary, distinguishing nonbailable detainees in a local jail. ${ }^{31}$ This distinction, while tenable in other contexts, ${ }^{32}$ is irrelevant to the instant analysis. The argument is essentially equivalent to the first, but the proffered distinction rests on the name of the institution and the locale of confinement rather than the motive for it. It suffers from the same shortcomings, however. How can incarceration be called something other than punishment because it is suffered in a different place or imposed for a different motive? The effect on the individual, the loss of his liberty dictated by the organized forces of society, is the same. The constitutional right against double jeopardy must not be defeated by such hollow verbal distinctions. Thus, despite the best efforts of courts and prosecutors to the contrary, the failure to grant credit for presentencing incarceration should be held to violate the double jeopardy clause as explicated by Pearce.

\section{UNCONSTITUTIONAL CONDITIONS}

A price may not be exacted by a state for an individual's exercise of a constitutional or statutory right, ${ }^{33}$ unless necessitated by a legiti-

29 Wright v. Maryland Penitentiary, 429 F.2d 1101, 1104 (4th Cir. 1970) (argument by the Attorney General; the court neither accepted nor rejected the argument, but left the application of Pearce to the state court).

30 See note 21 supra.

31 Bennett v. State, 450 S.W.2d 652 (Tex. Crim. App. 1970) (time spent in county jail).

32 The Supreme Court, recognizing the validity of the distinction, recently held that local jails are not the equivalent of state prisons in the awarding of good time for determining parole eligibility, but the Court left open the question of crediting pretrial local confinement against the prisoner's full sentence. McGinnis v. Royster, 410 U.S. 263 (1973). As the Court recognized, the New York practice it upheld concerned only the setting of a parole date: "while New York does deny good time credit for jail time in computing the minimum parole date under $\$ \$ 230(2)$, and (3), it allows such credit in calculating the statutory release date under $\$ 230(4) . "$ Id. at 1058 (footnote omitted). Although the presence or absence of rehabilitative facilities is clearly relevant in deciding whether a prisoner can be safely paroled, as the Court held in McGinnis, it does not alter the reality of the punishment inflicted upon a prisoner in a local jail. But see note 28 supra \& accompanying test.

a3 See, e.g., United States v. Jackson, 390 U.S. 570 (1968); Comment, The Chilling 
mate state interest. ${ }^{34}$ The burdened right must, of course, be actually exercised rather than waived for fear of the consequences. ${ }^{35}$ Pearce held that, absent identifiable behavior by the prisoner to justify it, a judge may not impose a harsher sentence on a successful appellant upon resentencing. ${ }^{36}$ Thus the state is forbidden to deter or burden the prisoner's right to appeal, except when the countervailing legitimate state interest of controlling prison deportment is served. ${ }^{37}$ Some lower federal courts have extended the Pearce holding, requiring that credit be granted for time spent in jail from the date of conviction to the date an appeal is dismissed, although a prisoner does not formally begin to serve his sentence under state law until the appeal is dismissed. ${ }^{38}$

An accused can extend his period of pretrial confinement in a number of ways. A simple plea of not guilty, requiring trial, delays sentencing to the extent that a guilty plea is more quickly disposed of. Exercising other procedural rights-such as seeking a suppression hearing-takes still more time. In these situations, there can be no "legitimate state interest" in denying sentence credit for pretrial confinement. The state's interests in bail or pretrial incarceration are to insure the presence of the accused at trial and to protect the public from a potentially dangerous recidivist. ${ }^{39}$ Neither interest has a rational nexus with the denial of credit for time spent in jail; on the contrary, they may compel a grant of such credit: otherwise the implication arises that punishment is the purpose of confinement. ${ }^{40}$

In many cases there is a voluntary exercise of rights granted by the state. Wright v. Maryland Penitentiary ${ }^{41}$. provides an excellent example. Wright spent over two years in jail from arrest to conviction, due in large part to his decision to have his first indictment declared invalid and to plead not guilty by reason of insanity, requiring mental and physical examination over a period of nearly a year. Although the court did not decide whether denial of credit for the time thus spent was an unconstitutional burden, such a denial is extremely chilling to

Effect in Constitutional Law, 69 CoLOM. L. Rev. 808 (1969); Note, Another Look at Unconstitutional Conditions, 117 U. PA. L. Rev. 144 (1968).

34 Compare North Carolina v. Pearce, 395 U.S. 711 (1969) with Colten v. Kentucky, 407 U.S. 104 (1972) (upholding the de novo trial system because of the absence of any inherent likelihood of vindictiveness).

35 Compare United States v. Jackson, 390 U.S. 570 (1968) with Brady v. United States, 397 U.S. 742 (1970).

36395 U.S. 711, 723 (1969).

37 See North Carolina v. Pearce, 395 U.S. 711 (1969); cf. Griffin v. California, 380 U.S. 609,614 (1965) (barring prosecutorial comment on the accused's failure to testify).

38 See, e.g., Hart v. Henderson, 449 F.2d 183 (5th Cir. 1971); Wilson v. North Carolina; 438 F.2d 284 (4th Cir. 1971); Robinson v. Beto, 426 F.2d 797 (5th Cir. 1970)

(per curiam) (construing Pearce broadly); State v. Williams, 262 La. 769, 264 So. 2d 638 (1972); Ex parte Griffith, 457 S.W.2d 60 (Tex. Crim. App. 1970).

39 See Stack v. Boyle, 342 U.S. 1 (1951).

$40 \mathrm{Cf}$. Short v. United States, 344 F.2d 550 (D.C. Cir. 1965).

41429 F.2d 1101 (4th Cir. 1970). 
the exercise of the rights involved. ${ }^{42}$ This argument is of broad application; anytime an accused spends time in jail exercising a right incident to fair trial, it is a chill upon the exercise of that right to deny credit for time so spent. Thus, time served in jail during the delay caused by electing a jury rather than a nonjury trial, or by requesting a hearing on a motion to suppress illegally seized evidence, should be credited to the accused if he is found guilty.

To extend this analysis further, should not even the period of detention from the initial plea of not guilty to final sentencing be credited? The delay is a direct result of the plea of not guilty; failure to credit it impermissibly burdens the right to plead not guilty. If viewed from this perspective, the failure to grant credit for postarraignment pretrial confinement is as constitutionally suspect as the failure to grant credit for time spent in jail while appealing a conviction. ${ }^{43}$ In short, denial of credit for pretrial detention may cause a constitutionally impermissible chilling effect on several of the accused's rights incident to a fair trial.

\section{Cruel and Unusual Punishment}

Federal district courts have held that the denial of presentence credit to prisoners sentenced to a maximum term violates the constitutional prohibition of cruel and unusual punishment. ${ }^{44}$ Assuming a maximum sentence, and no distinction between pre- and posttrial incarceration, ${ }^{45}$ failure to credit the former results in a period of confinement beyond the statutory maximum. Recognizing that fixing

42 See note 33 supra.

43 The court in State v. Williams, 262 La. 769, 777-78, 264 So. 2d 638, 641 (1972), noted as a matter of statutory construction:

In addition, the following [non-constitutional] reasons are suggested why a defendant should be given credit for time served pending appeal:

(1) Considering the long delays in perfecting an appeal, in lodging the record in this court, in setting the case for argument, in deciding the case and the application for rehearing, one could spend more time in jail waiting a final determination of his appeal than the length of the actual sentence. Delays on appeal have ranged to over two years in this court.

(2) Article I, Section 12 of the Louisiana Constitution and Article 314 of the Code of Criminal Procedure require that when the sentence imposed is five years or longer, a convicted accused cannot be released on bond while his appeal is pending. Thus, it is inherently unfair to penalize an individual by not giving him credit for time served while his appeal is being processed, a procedure over which he has no control.

(3) Society has extracted its 'debt' when a certain sentence has been imposed and when the defendant has served that amount of time in prison.

(4) The poor who could not afford to make bond pending an appeal would be imprisoned longer than those who could afford to make bond.

(5) It discourages a defendant's statutory right to appeal if he is not allowed credit for time served pending an appeal.

44 See, e.g., Parker v. Bounds, 329 F. Supp. 1400, 1402 (E.D.N.C. 1971). Since a bailable offense was involved, the equal protection clause provided an independent base for holding the denial of credit unconstitutional. For a discussion of the double jeopardy implications of the case, see text accompanying notes 22-26 supra.

45 See text accompanying notes $23-28$ supra. 
penalties for criminal acts is a legislative function, the courts held sentences beyond the statutory limits constitutionally impermissible cruel and unusual punishment. ${ }^{46}$

This argument is inapposite to some states; if the relevant sentencing statute grants the trial judge discretion respecting credit for presentence incarceration, ${ }^{47}$ the question whether he is permitted to deny credit, mete out the maximum sentence, and remain within the statutory limits becomes a matter of interpretation of state law. At least one state court, as a matter of statutory interpretation, ${ }^{48}$ has held the statutory maximum sentence to be a limit on the total time, both pre- and post-trial, that a prisoner should be confined for one offense. ${ }^{49}$

The cruel and unusual punishment argument, however, is apposite to $C o b b$. Alabama has no statute granting the trial judge such discretion; ${ }^{50}$ thus the statutory maximum sentence is the limit upon punishment for any given offense. Since pretrial incarceration is effectively and constitutionally punishment, ${ }^{51}$ and statutory justification for the additional punishment is lacking, this punishment is outside the statutory limits, rendering it constitutionally impermissible.

\section{CoNCLUSION}

It is disappointing that the court in $C o b b$ did not discuss the many constitutional issues involved in greater depth. It can be expected, however, that other controversies over the pretrial confinement credit question will arise shortly, providing courts with opportunities to assure the right of an accused prisoner to credit for presentence incarceration.

\footnotetext{
46 Although many lower federal courts have held that sentences within the statutory limits will not be considered cruel and unusual punishment, see, e.g., United States v. Lloyd, 431 F.2d 1160 (9th Cir. 1970); United States v. Tobin, 429 F.2d 1261 (8th Cir. 1970) ; Andrus v. Turner, 421 F.2d 290 (10th Cir. 1970); United States v. King, 420 F.2d 946 (4th Cir.), cert. denied, 397 U.S. 1017 (1970), the Supreme Court's recent landmark decision in Furman v. Georgia, 408 U.S. 238 (1972), leaves little doubt that entire statutory schemes may be found to constitute cruel and unusual punishment.

47 See note 9 supra.

48 For a discussion of relevant nonconstitutional factors properly bearing on statutory interpretation, see note 43 supra.

49 Jones v. State, 11 Md. App. 468, 275 A.2d 508 (1971); but cf. Williams v. State, 2 Md. App. 170, 234 A.2d 260 (1967).

${ }^{50}$ Cobb v. Bailey, 469 F.2d 1068, 1069, 1070 (5th Cir. 1972).

51 See text accompanying notes 25-32 supra.
} 